\title{
The 'Temple of Non-Being' at Tsitsernakaberd and remembrance of the Armenian genocide An interpretation
}

\section{T} his paper discusses and analyses the memorial complex of Tsitsernakaberd ${ }^{1}$ in Yerevan as an architectural and symbolic entity in relation to Armenian national identity in the aftermath of the Armenian genocide of 1915. How does this Soviet-era structure fulfil its role as a genocide memorial today, including its function as a forced substitute for the hundreds of holy places and the culture and life connected with them? On the one hand, this is only a small inquiry into the function of one building complex. Yet on the other hand, the topic is more essential than perhaps anything in history: the genocide memorial crystallises a set of profound questions, serious problems and agonising processes. An entire national existence can be crushed in a genocide and subsequently debased through its denial, resulting in existential problems such as, on the one hand, a pressure of assimilation for the diaspora, and on the other, severe socio-economic and geopolitical-military crises in present-day Armenia.

\section{National shrines: some background remarks}

National shrines function as points of encounter between individuals and history, due to their potential for generating propagative pulsations of collective memories and identities. How such shrines are de facto experienced, however, depends on the pre-knowledge and understanding of the particular national history, and that not only as data-content, but as a lived and experienced reality.

1 The name literally means 'Swallow-fortress' and is originally the name of the hill on which the Armenian Genocide memorial complex was built.
Moreover, the very idea of nationalism needs some rethinking. National identities, in the European sense of the word, are in our times insipidly defined by means of passports, and thus considered to be restricting and restricted, even old-fashioned. Therefore it is essential to question the (mis)conception that a 'national identity' should be defined according to state boundaries. In the known history of humankind, national identities and traditions have typically been preserved within multicultural empires consisting of endless ghettoes of divergent traditions and languages. The distinctive features of various groups, such as Armenians or Jews, have been protected in these ghettoes, with more or less selfgovernance in internal matters. Indeed, Armenians are a good example of a people who have been proud of their national identity, regardless of their country of residence or de jure citizenship.

What we nowadays call 'multi-cultural' societies in fact seem to be postmodern monocultures in which the remains of a diverse range of cultures are intermingled, each cultural tradition bereft of its definitive role in communal life; in this context, various long-established groups are set to lose their specific characteristics little by little. This process will take several generations, as the intermingling is still in its early stages.

Armenians, in fact, were one of the first people to develop the idea of a national identity based on a common language, history, set of customs and beliefs, expressed in terms of a philosophy of history - and independent of state boundaries. During the emergence of Armenian history writing, circa the fifth century AD, the Armenians inhabited vast districts which were divided among and ruled by the Roman and Persian empires, often as semi- 
independent vassal states. In spite of the complexity of the situation, the works were entitled a 'History of the Armenians', covering the nation as a whole, even though certain practical aspects would have favoured a more locally oriented approach. ${ }^{2}$

In the case of the Armenians, nationalism and national shrines are not to be understood on the basis of modern nationalism, which is defined by state boundaries and nationalities established on citizenship rather than culture, language, history and religion.

\section{The memory of a genocide reconsidered}

If we are conducting a philosophical analysis of a memorial of a genocide, what exactly are we talking about? In brief, the uniqueness of genocide as a phenomenon - in comparison to massacres, wars and other disasters - is in the ultimately ontological character of the project. In philosophical discussions of genocides, the concept of an 'ontology of genocide' has developed around the fact that genocide involves not only mass killings but also a systematic attempt to carry out an annihilation of a collective existence in the past, present and future. ${ }^{3}$ The annihilation of the past includes the destruction and reuse of national and sacred buildings, the destruction of archives and libraries and the devastation of graveyards. Ultimately, the most serious consequence of genocide is an annihilation of the future: the vacuum of tens of millions of souls and the culture they would have created. In such an enormous vision, it is rather irrelevant whether greater or smaller numbers of individuals manage to escape and survive in physical terms: private survivals can neither continue nor bring back the national collective existence.

On the whole, genocide is ultimately about memory, and all the more so in the case of the Armenians, upon whom the crime is is still slowly being perpetrated as a cultural genocide, including

2 The history writing itself was financed by local nobility who might have preferred a more local approach.

3 In the case of survivors, there is a new mode of existence: post-genocide mode of being. For a discussion of the philosophical approaches to the Armenian genocide, see the articles of Marc Nichanian ('Testimony: from document to monument', 41-62) and Michael Papazian ('Philosophy and the age of genocide', 19-26) in Hovannisian 2007. the destruction of monuments and a denial of history. In fact, the ultimate aim of a genocide is to achieve a situation in which no one knows that this particular nation ever existed. Such a setting unavoidably, and unfortunately, means that without commemoration one is unwillingly fulfilling the ultimate wish of the perpetrators. In other words, those who want to be ethical, are, so to say, doomed to commemorate I say 'doomed', for those who consider forgetting as essential to the health of society are also right.

It is said that memory and identity go hand in hand. ${ }^{4}$ When a traditional national identity is lost, the most an individual can do is keep the fragments of memory. And in the case of a genocide, this is by no means easy. There are enormous psychological barriers and practical difficulties in dealing with the subject, and even if these are overcome, there is a serious structural problem; namely, the paradox of genocide remembrance - this is my conclusion after visiting dozens of Jewish and Armenian museums and memorials and reading hundreds of books on the subject - is that the customary focus on victims, victimhood and methods of annihilation, important as it is, effectively puts the focus on the perpetrators.

This has obvious negative consequences. Firstly, commemoration implicitly serves as an indirect tribute to the efficiency of the perpetrators. Secondly, the uniqueness of the culture annihilated is not set forth, and the result is just another variation on the theme of universal human suffering. And so it happens, in the course of history, that after several genocides the observer is more cynical than ever: one more massacre, one more iron wire, one more crying child, one more heap of skulls.

Therefore, I find it essential and necessary that the remembrance of genocide should concentrate somewhat less on the activities of the perpetrators and more on the life that was destroyed. What was unique about this particular culture? What did the world lose in this particular genocide? This is to shift the focus onto what was annihilated, instead of in what way it was exterminated. Moreover, this would also be a proper tribute for those who perished: who would not prefer to be remembered for the life they lived, rather than for being an object of torture and massacre?

4 For more discussion, see Stone 2013: 155. 
In the case of Armenians, questions concerning cultural contribution and national character are met with answers that are distinctive in numerous ways. Armenian culture stood out in the northern Middle East in many respects, having a distinct IndoEuropean language with no close relatives; a unique alphabet with no parallels; an ancient tradition of distinctive architecture; a visual culture of creative pictorial art in the midst of Islamic nations with no similar art forms; engravings on stone and paintings on enamel; elegant folk dances, melodic folk music and refined mystical chants; endless shrines and monasteries; unique social customs and beliefs. Sacred caves, sacred trees and holy wells - even sacred fish. ${ }^{5}$ All this until April 1915.

The variety constitutes the content for the horror of genocide and the challenge for dealing with its memory: ancient traditions of art, culture and spirituality were wiped out completely in a few weeks. To add to the bitterness, many cultural forms or instances in the fields of, say, architecture, handicraft, cooking, music, had been taught by Armenians to Turks over the centuries, with the result that every European today knows various old Armenian phenomena only in the forms their Turkified versions, and consequently the rare instances of original Armenian culture are considered as 'Turkish influences', sometimes even by serious scholars.

Personally, I have had a special interest in the monasteries that functioned in the Armenian districts. Pilgrimages and holy places were an essential part of traditional Armenian culture before 1915. There was a monastery within walking distance of every Armenian village, and all the national feasts took place at these sacred places. Monasteries had their own pilgrimage songs and villages performed their own dances in the monastic courtyards. Since April 1915, the meanings and identities of the Armenian sacred places and all public spaces were neutralised; ancient traditions of pilgrimage songs and dances vanished into thin air.

As a consequence, on facing the last remains of West Armenian culture one has to make a choice; to pass by, or to stop? To forget or to remember?

For half a century, no public memorial was permitted in Soviet Armenia, on suspicion of national-

5 Instances of sacred fish in Karin (Erzurum) district are described by John Yervant (1988: 6). ism. In the end, however, a memorial complex was allowed to be constructed in Yerevan. In what follows here, the major question is: how does this Soviet-era structure fulfil its role as a memorial of a genocide taking into account its function as a forced substitute for the hundreds of holy places, culture and life connected with them? Before answering that question, however, we need to outline briefly the place of such a question in a contemporary discussion of the issue.

\section{The memory of genocide as an architectural problem}

In recent decades, a number of Holocaust museums have been constructed in America and elsewhere. A whole new area of debate, dealing with the relationship between architecture and genocide has emerged in the wake of these projects.

In brief, the basic architectural dilemma of the genocide museums is that, on the one hand, the buildings should be solemn and magnificent enough to fulfil their function in honouring the victims and the memory of what has been destroyed; yet on the other hand, an architecture that is too outstanding and extraordinary may take the main focus away from the exhibition and its content. Moreover, if the architecture is too lovely and offers gentle pleasure or too much serenity, the result is bizarre: aesthetic pleasures are being derived from the atrocities. ${ }^{6}$

As a result of these tensions, the genocide museums tend to be massive and rather roughly built complexes unadorned by delicate ornamentation. Moreover, the focus is strongly on the event of the annihilation and its character. James Ingo Freed in his architectural design (for the United States Holocaust Memorial Museum) even considered and applied 'the rhythm of the Holocaust', defining it as a 'series of sharp changes followed by relative lulls' (Rotem 2013: 124).

It is to be noted, however, that even in the case of Jews, museums focusing on Jewish life before Shoah are surprisingly rare. This is largely an outcome of the thorough changes in the Jewish identity during modern times, and especially after the genocide. ${ }^{7}$

6 For a discussion of this problematic and its solutions in Jewish Holocaust museum architecture, see Rosenfeld 2011: 262-8.

7 Most museums and other forms of remembrance are planned and constructed by (American) secular Jews who are considerably distanced from the traditional Jewish way of life, based on halakhah. Consequently, 
Evidently, the tendency towards massiveness, roughness and lack of beauty may also go too far. In particular, the Holocaust memorial in Berlin has been criticised as 'too big, too heavy-handed, too divisive, and finally just too German' (Rotem 2013: 157). From an Armenian perspective, however, such problems are very much secondary compared with the fact that it is at all feasible to have memorials in the country responsible for the destruction in the first place.

Architectural tensions also appeared in Armenia, albeit in a different way. In Yerevan in 1965, on the 5oth anniversary of the genocide, the effects of long silence and lack of remembrance exploded into a series of massive demonstrations with hundreds of thousands shouting in the streets. Unheard in Soviet Union, the events nevertheless did not hinder the process of approving a place of remembrance.

The memorial place was to be created in the context of a peculiar architectural tension between the demands and style of socialist realism on the one hand, and concern for traditional Armenian architecture on the other. The Armenian diaspora was largely cautious of the former and enchanted by the latter. The topic had been discussed for half a decade, and efficiently prepared and lobbied for in Moscow in 1964 by Hakob Zarobyan, the first secretary of the Communist Party of Armenia. The fundamental problem was that there was no equivalent monument for any analogous phenomenon, either in Soviet Union or anywhere in the world. In the preliminary discussions, there was even an idea put forward of creating a memorial park containing one and half million trees! Overall, the whole process, from lobbying the Soviet government, to the mass demonstrations of 1965 , to the creation of a national shrine, was a unique event in the Soviet Union.

\section{Architectural and political games}

The architectural competition in Soviet Armenia was a bizarre process involving numerous complicated bureaucratic manoeuvres. The procedures have been researched and analysed recently by Karel Balyan

there is a strong tendency to show the annihilated European Jewish life in its most modernised and westernised forms. For example, the Hollywood movies on the Holocaust repeatedly fail to show traditional religious Jews and their thought-world - the ordinary Jewry of Eastern Europe.
(Balyan 2015: 15-38). It was an exceptional process, with some tragicomic features.

In the first phase, there was a commission for seven architects, mainly to amass and outline possibilities and ideas. The jury included some remarkable cultural characters, such as the writer Hrachya Kochar and poet Paruyr Sevak who both had a profound understanding of the tragedy and the range of its effects. All seven proposals took the form of memorials for the national tragedy alone, but the jury decided to include in the project an element of rebirth that would express the Armenians' will to live, and symbolically indicate hope for a brighter future. This was due to the fact that 50 years had passed and the Armenians were still in the process of recovering from the destruction. Accordingly, a new, open competition was organised (Balyan 2015: 17-21).

The second phase was run by a jury of thirteen officials, mostly professionals in city construction and architecture, including modernists and avantgardists, yet all politically reliable characters. They were concerned - if not personally, at least for Moscow - about the demands of social realism, which were not to be openly challenged, particularly not in the name of any kind of national or Christian symbolism. Thus the basic demand was for functional architecture with no performative elements. Among the oddities that the documents reveal is that in the Russian assignment of the competition there was an explicit demand for an 'obelisk', which may well be a mistranslation from the Armenian kotogh, which means a 'monument,' 'pillar' and 'obelisk'. ${ }^{8}$

Of the sixty-nine anonymous participants, eight were chosen for the final round. The projects were given names that varied from the politically correct ('Flag of ASSR') to the rather national ('Mush'), most being somewhere in-between with names like 'Red flower', 'Rock', or 'Fire', in addition to two different works both entitled 'Phoenix.' ${ }^{9}$ However, the jury refused to award the first prize, sharing out the second and third prizes instead. The chosen ones were the 'Flag of ASSR' by two young architects, Sashur Kalashyan and Arthur Tarkhanyan (known for his unique Kino Russia in Yerevan), and 'Phoenix'.

8 See Balyan 2015: 23. The variety in meanings is due to the fact that the earliest Armenian monuments were pillars.

9 These are merely code names for the anonymous projects, not names of the actual works. 


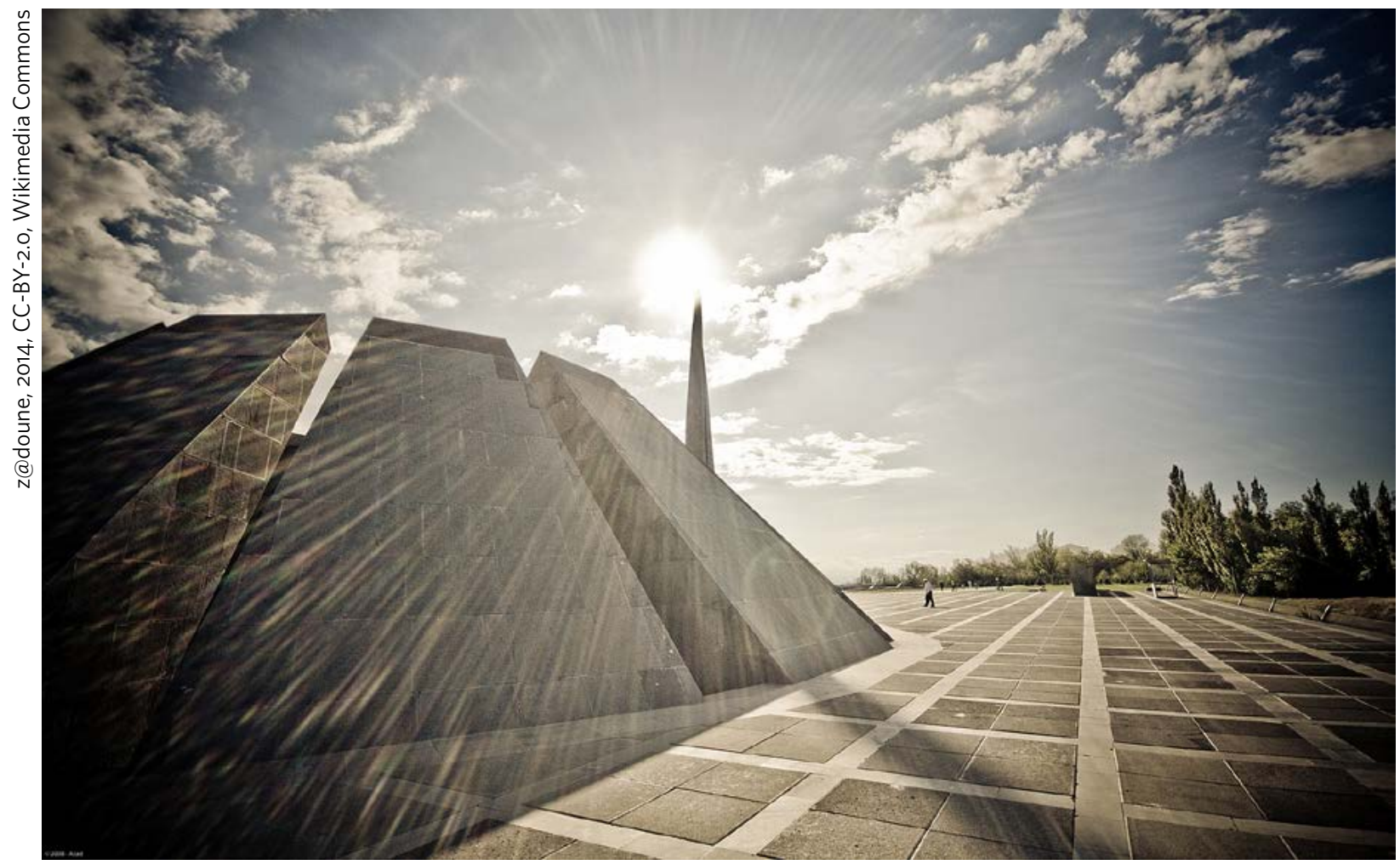

Obelisk - symbol of recovery and rebirth.

Only now were the prizes for the first phase granted, the result being two sets of winners with no actual winner! Oddly, no document shows a single positive remark being given to any of the works that were rewarded by the jury - not even a word as to whether something should be built or not.

The oddities can be explained by the nervous political atmosphere in the aftermath of the counterreaction to Stalinism and ousting of Khrushchev in 1964. The authorities were afraid, with good reason, of the possibility that the winds could change once more and the whole project could be disqualified as exceedingly nationalistic. Therefore, they wanted to cover their backs by keeping a clear distance from the procedure and by showing to Moscow that the process was strictly under their control.

Even the choice of location was a twofold enterprise. For Moscow, if necessary, it could be presented as a low-profile choice, Tsitsernakaberd being a rather isolated, forested hill outside the city centre - at least on the map and in photographs. In practice, however, the hill was outstanding and superbly visible from the western aspect of the city centre, including its main entrance. Moreover, the city was rapidly expanding into the area, so that it was inevitably to become a key central location.
Subsequently, a third round was declared, but it was only open to the winner of the first phase and the two best entrants of the second phase! These three were also awarded 400 Soviet roubles. The work of Tarkhanyan and Kalashyan was dropped, but then it turned out that none of the remaining works could gain approval through a vote. In the end the leaders of Soviet Armenia interrupted the process, which was turning into a total quagmire. They were convinced by the head of the union of architects that the best option was the one by Tarkhanyan and Kalashyan which had been left out of the final round. Interestingly, the decisive arguments in the discussion said that the plan was easily understandable for visitors: twelve khatchkar-like bent pylons represented sorrow, and this would be understood by anyone, with no need for further explanation. Once the leaders of Soviet Armenia were convinced, the Kalashyan and Tarkhanyan proposal was voted the winner, regardless of all the previous procedures and contradictory votes. ${ }^{10}$

10 For more details, see Balyan 2015: 34-5. Cf. Tsitsernakaberd Memorial Complex website. 


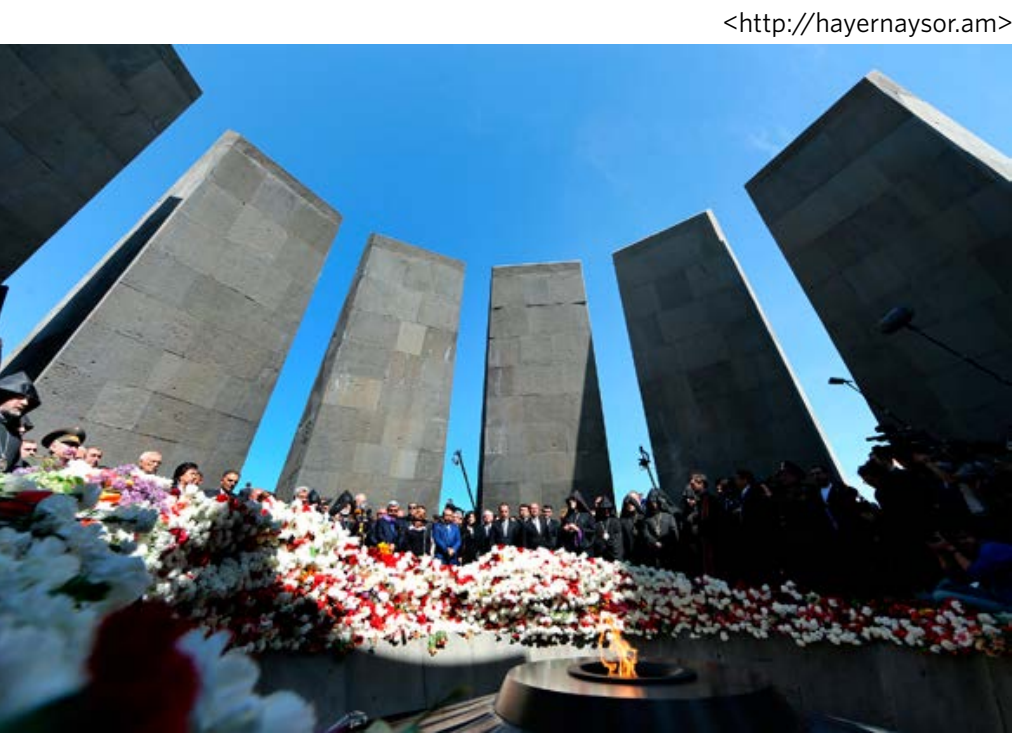

The highest political and religious leadership of Armenia around the eternal fire on April 24.

The jury also set four demands concerning changes to the plan, but two of these were so abstract that they could hardly be applied in any reasonable way. The most relevant one was that the obelisk was to be narrowed somewhat in order to make it look 'less like a rocket' (Balyan 2015: 36-7).

The aesthetic considerations were rendered more dramatic by the fact that the scattered remains of the Armenian nation had no proper places of remembrance anywhere. Needless to say, in Turkey the places of mass killings, or the former pilgrimage centres, have no memorial signs. In Soviet Yerevan, the sole place of remembrance for the genocide until 1967 was the grave of Vardapet (priestmonk) Komitas Vardapet, the master of Armenian folk music and liturgical chants, which attracted thousands of visitors each year on April 24th.

The new complex had to serve as a memorial to the whole tradition of spirituality and culture based on it. It was to become 'a unifying symbol for Armenians scattered all over the world' (Arevshatyan 2010). Perhaps largely for that reason, the architects had in their original plan the interesting idea of using music by Komitas and Makar Yekmalian arising from the middle of the memorial (Balyan 2015: 39-40). The choice of composers clearly indicates that the music, emerging from within the cross-shaped plan, was to be a liturgical chant (perhaps Ter Voghormyan, a hymn for the dead from the end of the liturgy), thus filling the temple space with sacred awe and liturgical associations. The plan never came to pass, but nowadays other kinds of music may be played in the yard on the way to the memorial.

Fortunately, the massivism, colossalism and colourlessness of Soviet style that was applied happened to be perfectly in line with the unique challenge of genocide memorials, surprisingly well in line with the elaborations of the later Jewish discussions. In Tsitsernakaberd, there is no such sentimental beauty or fragile attractiveness that could misdirect the visitors' attention. The sobriety of the architecture silently bears witness to the vast dimensions of loss. In its architectural ethos, the Tsitsernakaberd complex seems to be related to Yad Vashem and other Jewish museums and memorials of the Shoah, even though it antedates them. ${ }^{11}$

Nevertheless, some de-materialising features were needed to provide mental space for a profound and solemn commemoration. These are provided by the use of a tall obelisk and eternal fire, in addition to the presence of Mount Ararat in the landscape, the width and extensiveness of which serves the same purpose. The presence of Ararat, a national symbol par excellence for Armenians, had been important for the architects since the very first draft.

\section{The memorial space in Tsitsernakaberd}

It has become customary in Holocaust museums to have an indoor museum for information and a separate outdoor space for reflection and remembrance. Tsitsernakaberd shares the same basic pattern since the inauguration on the museum in 1995. The museum has been completely renovated recently to fit in with the modern demands of visuality. ${ }^{12}$ The commemorative element, which we are focusing on, is located somewhat unusually almost above the museum, due to museum's location in a slope. ${ }^{13}$

The memorial space of Tsitsernakaberd consists of three main areas and their surroundings, including trees of remembrance planted by world leaders.

11 Yad Vashem in Jerusalem was established in 1953, but the present main museum building by Moshe Safdie is from 2005.

12 The old museum has been analysed by Jinks (2014: 39-52).

13 One recalls here the myth detailed at the end of the national epic David Sasuntsi, in which the glorious yet vanished life of Armenia remains hidden inside the mountain; in Tsitsernakaberd, the contents of the lost West Armenian life are likewise in the rock. 


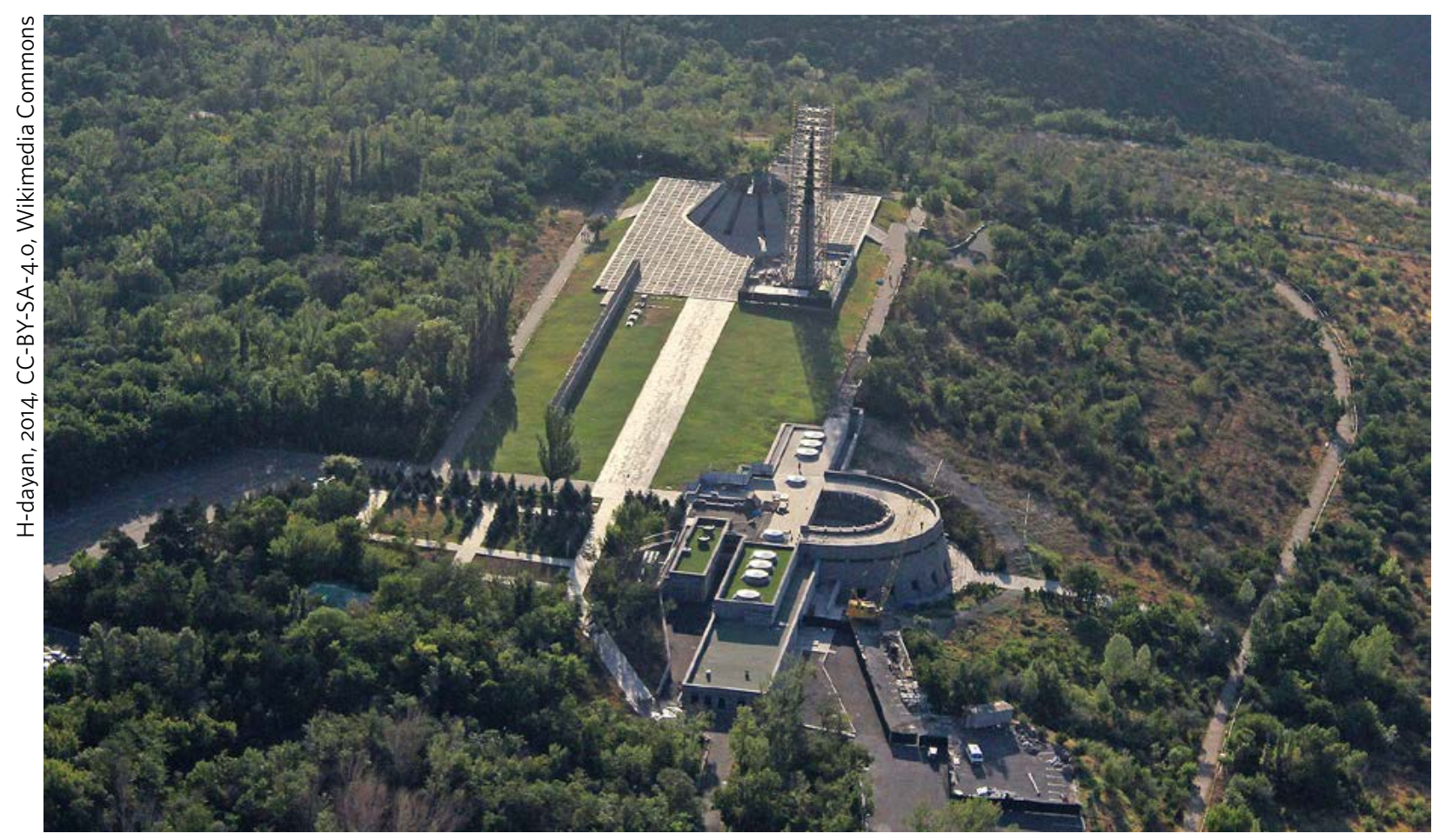

Museum and Institute in the right lower corner of the area, trees of remembrance to the left of the museum.

Firstly, there is the pavement with a wall of remembrance $^{14}$ on its left side. The pavement leads directly to the commemorative space customarily known as the 'Sanctuary of Eternity'; I have chosen to call it the 'Temple of Non-Being' in order to highlight the philosophical concerns arising from the ontology of genocide. It is a commemorative space constituted of huge, bent, stone-like entities that mark an open circular space with an 'eternal fire' in the midst. Thirdly, there is a high, finely pointed obelisk nearby, which is nevertheless outside the path and slightly out of of line.

The 44 metre high obelisk, partially split, has evident semantic power and inspiring semiotic potential. ${ }^{15}$ According to the prevalent explanation, it symbolises the rebirth of the Armenian nation namely, the one that took place in Soviet Armenia, then de integro in an independent Armenia. This makes perfect sense in its setting: the temple curves downwards, while the obelisk on the right side boldly stands up. But it rises from the side, not the middle: the new Armenia stands not in her heartlands, but in her eastern corner.

14 The wall was completed one year after the inauguration.

15 In the original plan, the obelisk was made of iron, but due to rust concerns, it was covered with basalt slabs.
I would argue, however, that another nuance of meaning and function has actually developed in the obelisk, due to its visual force, especially when lit up at night. Given the fact that the obelisk dominates the landscape from afar and is the only part of the memorial complex that is visible both from a distance and in the dark it serves as the primary reminder of the genocide in the silhouette of Yerevan, functioning like a finger of remembrance reminding one of the unresolved and unforgiven annihilation. In the Armenian mind, the function of the monument is not so much to arouse feelings of sorrow, but rather to assert a claim for justice, and a certain willingness to show to the world, including enemies, the monstrous content of the destruction, as Balyan noted (Balyan 2015: 51).

From this wider perspective, Yerevan itself is the rebirth per se of the Armenian nation; the cry of the obelisk is a cry of remembrance of the absurdity of history: if it had not been for the Turks, the Armenians would be a great nation from sea to sea and not restricted to its present status as a tiny slice of land, consisting of barren and rough mountains, amidst hostile neighbours.

The pavement by its very existence underlines the fact that the memorial space of Tsitsernakaberd is not meant merely to be observed, but participated in: one 


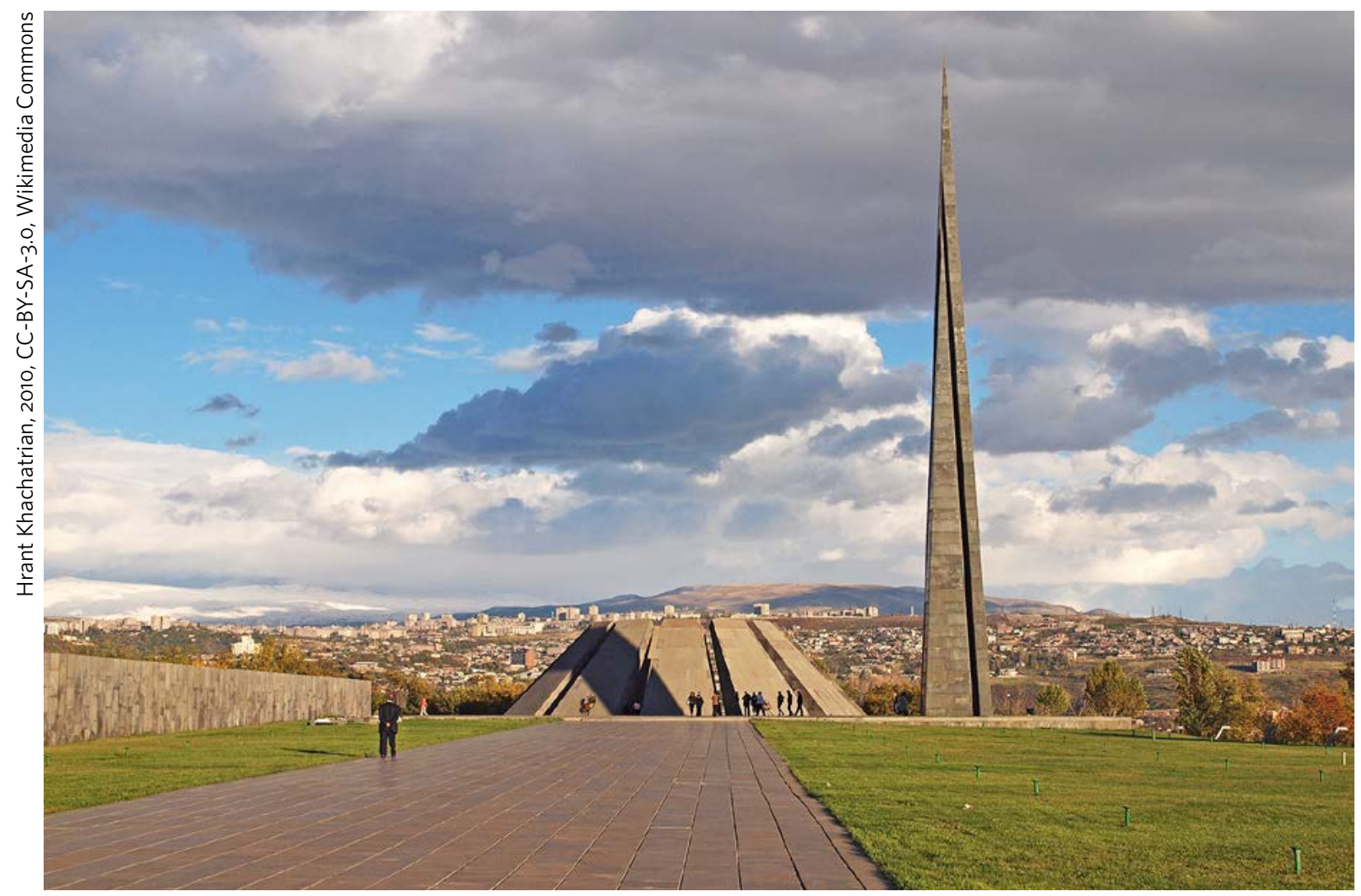

When approaching the pylons, the wall of remembrance is on the left and the obelisk on the right.

is to walk the path, enter the space, participate in the presence of absence. The demand for participation is also what distinguishes it from the other Armenian monuments of rebirth, like the one in Aparan (see Stepanyan 2015: 5-10).

The area opens towards the the Armenians' eternal, holy mountain; Ararat has been sacred for the Armenians since pre-Christian times, and is also holy for the Church. Accordingly, Ararat has been an endless source of inspiration for Armenian poets and painters, bankers and priests, pilgrims and pranksters alike. When walking the pavement, the holy mountain is on the right-hand side - the biblical side of salvation. Traditionally, holy mountains are habitations of gods, elevations of the earthly towards the heavenly. With her transcendentally glimmering icy whiteness during the hot and dry summer days, Ararat functions as an opening to the other reality, a true gate of heaven. Today, being on the Turkish side of the border, however, it also serves as a constant reminder of the annihilation, so that it opens for Armenian minds the gates of hell.

Approaching the memorial in Tsitsernakaberd, each step is a commemorative and participatory act, a silent reflection in the steps of the deceased, not least because of the character of the implementation of the genocide. Given the fact that hundreds of thousands perished during the death marches, either in killings or through exhaustion, footsteps indeed represent most dramatic commemorative acts, full of meaning and value.

On the left-hand side - the biblical side of doom there are inscribed, in Armenian script, the names of some of the most remarkable West Armenian towns. The names were engraved onto the wall in 2002. In a bold move, they are left without Russian or Western transcriptions - 'Those who have eyes, let them read'. The idea is not to deliver information, but to create space for commemorating the loss. ${ }^{16}$ Names such as Mush, Sasun or Bitlis are both historical and mythical for Armenians, due to the endless number of monasteries, books, songs, dances and poems (including the national epic Davit of Sasun) which are connected with these very places. As a matter of fact, these constitute the core of Armenian culture which

16 In Yad Vashem, Jerusalem, the corresponding 'alley of names' (of Jewish communities) is much larger yet located far from the main museum and is visited by very few. 


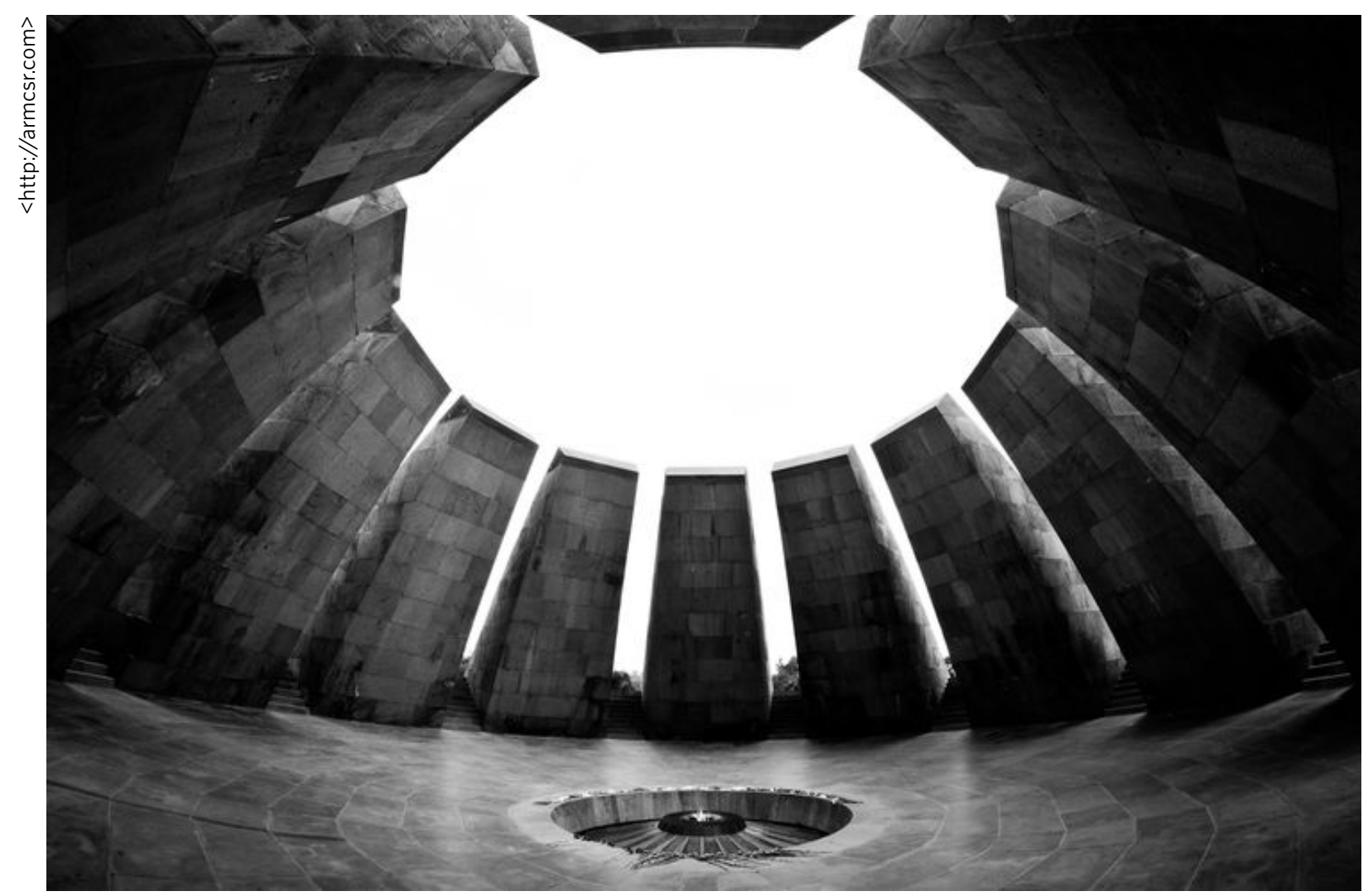

The concrete openness also serves to indicate the openness of Armenian question.

is still being read, sung and played in Yerevan today. During the century in which they have been absent from these very places, however, the names have become more and more mythical and less concrete.

By comparison, in Jerusalem visitors in Yad Vashem may observe lists of endless names of the annihilated individuals. In Yerevan, the lack of names is just as striking. Due to the exhaustiveness of the destruction and its continuance in our time in the form of cultural genocide, it is too late to prepare such lists - the battle against oblivion has largely been lost.

\section{The Temple of Non-Being}

In Yerevan, the pathway leads to the central sanctuary, a symmetrical, open space consisting of twelve pylons of basalt, with an eternal fire in the middle. From far away, the structure could be seen as a surrealistic version of a traditional Armenian Church that has lost the top of her dome and the solidness of her shape - which features happen to be the most characteristic of Armenian Churches. Simultaneously, the pylons reach out to comprise the shape of Ararat, although never quite reaching the unapproachable.
According to Balyan's interpretation, the pylons are carrying the sky - not symbolically but rather concretely, in the same sense that the ancient Armenian homes were open to the sky in the middle, above the fireplace. The set of pylons constitutes the whole material, national and spiritual sorrow, against which the sky rests (Balyan 2015: 51). In any case, the temple is open to the sky, leaving the light and conditions subject to changes in natural conditions, which functions as a sign of helplessness and vulnerability. The concrete openness also serves to indicate the openness of the Armenian question: no apologies, no compensations, no change in Turkey's antiArmenian policy. And surely no healing.

Instead of walls, there are the commemorative elements (pylons) that are said to symbolise the lost provinces. This in fact means that the post-genocide national temple is constituted of the memory of lost spaces - and after a century, it is more accurate to say: the vanishing memory of lost spaces. The emptiness of content and solidity of the material seem to underline the anguish of loss and the absoluteness of absence on the one hand and the persistence of memory on the other. 
The number of elements, however, adds up to the symbolic and biblical twelve, even though the actual number of Armenian provinces in Eastern Anatolia was less. ${ }^{17}$ Moreover, it is debatable how the interpretation of the site representing twelve provinces originated. A cult of lost lands would have appeared to be too nationalistic in the Soviet Union, and in fact it seems that reference to this interpretation is nowhere to be found in the early sources (Ter Minassian 2007: 184). Instead, it has spread and developed as an oral tradition which has probably existed all the time in Armenian minds. This is also philosophically relevant, for it shows that written words do not necessarily have the monopoly on the meanings of spaces and constructions. In any case, there is the logic that the pylons cover and protect life, or the lack of it, symbolised by the fire, and in that sense it is logical that the areas in which Armenians lived are symbolised by these structures.

The loss of history is emphasised by the total absence of symbols in the space. This in turn leaves space for interpretation. The absence of symbols also serves as a silent symbol of the totality of the annihilation. Moreover, it serves to show the power of oblivion, for the genocide wipes away content leaving empty surfaces instead. Needless to say, the Soviet era enforced the same effect, leaving an unwilled testimony of her emptiness on the walls.

The basalt slabs are also reminiscent of the basic Christian symbol of Armenianness: the crosses engraved in stone (khachkar, 'cross-stone'), which for centuries have been erected everywhere to commemorate memorable events or persons. The basic symbolism of khachkars is that of life: the traditional Armenian cross is an ornamented tree of life that blossoms in all four directions, symbolising universalism and cosmic harmony in Christ. In Tsitsernakaberd, however, the crossless khachkars do not signify life; rather they silently and inanimately bend down towards the centre, without any vital signs - or any sign whatsoever. Here the Soviet cautiousness concerning Christian and national symbols happens to serve the memory and philosophy of genocide in a dignified and profound way. The only symbol in the complex is an almost imperceptible circle, that of eternity, in the metal ring around the eternal fire.

17 The details have varied over time. In the Ottoman system, the number of vilayets in the corresponding areas was six.
To define the elements as 'pylons' adds another associative nuance to the meaning. In ancient temples, massive pylons functioned as entrances. The Temple of Non-Being is as if constituted by gaps that function as mere entrances (and exits) - an effective way to express the idea that the content is non-existent.

The pylons as a whole have also been compared with a crown of thorns (Ter Minassian 2007: 184), which is an evident Christian reading which does have fervent subtexts in the memoirs of survivors. During the massacres, the destruction was widely understood and interpreted as participation in the sufferings of Christ, and the process was referred to by both clergymen and lay people as 'Golgotha', even with the 'Stations of the Cross.' ${ }^{18}$ After the destruction, Golgotha remained one of the key terms for the destruction. Perhaps the most remarkable of all survivor memoirs, that of Grigoris Balakian, is called Armenian Golgotha. A century afterwards, one can say that the Stations of the Cross have vanished, but the crown of thorns remains.

The relation to the cross is not an artificial interpretation, for according to the architects themselves, it was essential that the whole project should be in shape of the cross, and that the visitors take part in the structure by entering and being present, the central point being of a cross-like layout. The presence of the cross in the total plan is concealed, however, although it can be distinguished from the original layout drawing. The architects also emphasised the dynamic disposition and asymmetry that were designed to bring about a sense of growth and movement. In a word, genocide implemented on a religious basis was participation on the cross of Christ per se, and a visit to Tsitsernakaberd is a symbolic participation in the same reality.

18 See, for example, the memoirs of Vahram Dadrian (2003: 55) and Elise Hagopian Taft (1981: 56). In her memoirs, entitled Towards Golgotha, Arda Arsenian Ekmekji described the process of approaching the end in death marches as Via Diolorosa and Golgotha: 'It was impossible to sleep - we were obsessed by our via dolorosa, the road to Golgotha - to death, to the graveyard.' She even used the image without explanation, as if it was to be taken as understood: 'The next morning [12.11.1915], the caravan moved toward Golgotha, and we started climbing the heights of Mount Amanus' (Arsenian Ekmekji 2011: 94). 


\section{Echoes of pilgrimages}

Moreover, the commemorative act constitutes a continuum, or perhaps rather an echo, of the spirituality of Western Armenians. Over the centuries, Armenians made pilgrimages to nearby monasteries, especially during the annual temple feasts. Present day Armenians instead walk to Tsitsernakaberd on April 24th, in addition to possible 'smaller pilgrimages' throughout the year. Following the cutting off of the ancient pilgrimage routes and destinations, there is no other peregrination event to unite the Armenians.

The parallelism may not be explicit, but it is also not artificial. The two phenomena contain astonishing parallels. Before the genocide, the traditional pilgrimages culminated in entering the holy space and touching the sacred by venerating relics and participating in the sacraments. The post-genocide 'pilgrimage' to Tsitsernakaberd culminates in entering the memorial space in a movement which takes the walker one and half metres downwards - the steps cause everyone to bow their heads - observing a short silence and leaving red or white flowers around the eternal fire. Some pray, albeit perhaps more with gestures than words. There are no prayers or rites - or religious beliefs, for that matter - that are useful in dealing with genocide.

The parallels with the pre-genocide pilgrimage are worth observing in detail:

\section{Traditional pilgrimage}

$\theta$

Relics and sacraments

Veneration by touching

Verbal veneration

by prayer and worship

Receiving

a spiritual blessing

Encountering the presence

Gratitude to God

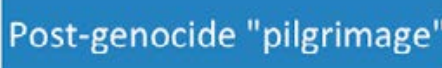

Eternal fire

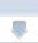

Fire: non-touchable

Veneration

by silence

Leaving

a concrete object (flower)

政

Encountering the absence

Bitterness to fate
In brief, one may say that the content of Armenian national processions has been turned upside down. And on the other hand, if the phenomena can be seen to be incomparable, it makes the parallel even more painful, for the visit to Tsitsernakaberd functions as a forced substitute for the traditional processions of a sacred and national character, whether the phenomena are related or not.

In addition to personal losses of families, the Armenian nation lost almost all of her holy caves, sacred trees and sacred wells, even the landscapes of the national epics and songs, legends and fairy tales. In the annihilation of the monasteries, the Armenians also lost their saints and tombs, relics and sacred artefacts that had been venerated for ages. As a result, the annual commemoration in Tsitsernakaberd has an immeasurable gap to fill as an act of collective memory.

Before 1915, pilgrimages and religious feasts culminated in traditional circle dances that continued for hours, even days, in the courtyards of monasteries. The circle is a symbol of eternity, present also in most khachkars. In a similar fashion, the Temple of Non-Being, by virtue of its architectural layout, stands as a never-ending circular dance. However, the dancing stones are bent and the movement is turned inwards - somewhat like an eternally frozen step in Kochari, one of the classical national dances of Western Armenia.

The medieval Armenian churches were mystical temples in which the contents of Christian mysteries were preserved and protected from outsiders; the sacred vessels were hidden in secret cavities, the most sacred rites were performed behind closed curtains. In Tsitsernakaberd's temple of commemoration, there are no walls, no doors; there is no roof, no altar, no sacred objects, nothing to hide. It is as if the space is constituted by a lack of everything that used to make up the Armenian soul, Armenianness, from 301 to 1915 .

The only presence is that of fire - a silent, nondiscursive element, a destructive entity, but also a sacred one. In ancient Armenian homes, there used to be a sacred fire in the middle of the house. ${ }^{19}$ Fire, as the object of veneration in pre-Christian Armenia,

19 In Christian Armenia, the sacred fire was kindled on the feast of diyarnentaratš (in dialects: derindes, tern$d e z$, derndadz) in February, and preserved in houses for months, even for the whole year. 


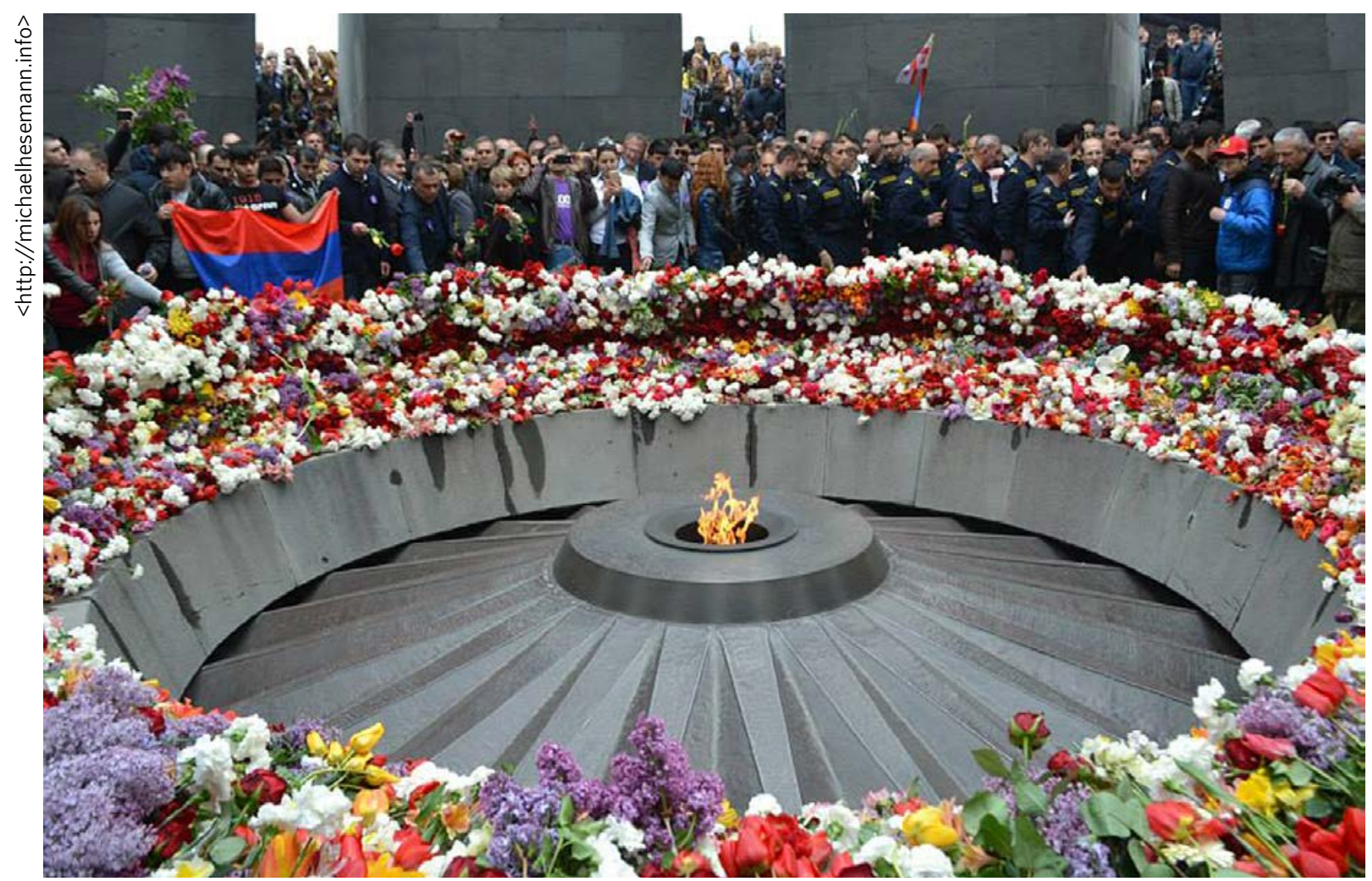

Armenians from all over the world leaving their flowers around the eternal fire on April 24.

is also an implicit sign of a mistrust of Christianity, the observance of which was the key factor behind the genocide, and also the actual criterion of its implementation. Even today, many Armenians are bitter towards their Church for having taught them to turn the other cheek instead of defending themselves, and the revival of Christianity in Armenia has been rather slow, in comparison with Eastern European countries.

\section{April 24th: the national procession}

Following the inauguration of the memorial obelisk in Tsitsernakaberd on November 29th 1967, people started to walk to the monument in an unceasing flow that continued late into the night. Since then, the ritual walk has taken place every year on April 24 th, the memorial day of the genocide. The area is closed off from quite a distance, so the walk is easily a couple of kilometres long. On the centenary in 2015 the massive flow of walkers through the area continued over a couple of days.

One can easily see here a symbolic re-enactment of the death marches: the walk functions as a commemorative participation in the fate of the annihil- ated. On the other hand, however, it is also a powerful 'life march' which emphasises the experience of being alive and functions as a unique expression of the collective survival: we walk, therefore we exist.

Moreover, the commemorative walk is also a collective reminiscence of the ecclesiastical processions that for centuries were at the core of feasts in Armenian villages, towns and monasteries. And more than that, the flow of people is a functional substitute for pilgrimages to the holy places such as Surb Karapet in Mush, which used to attract Armenian pilgrims from Poland to Georgia. ${ }^{20}$ The result is a rather epic mode of remembrance: collective memories and the sense of national existence are experienced nowhere like they are in Yerevan on April 24th.

Tsitsernakaberd creates an open, unending narrative in which the national disaster is experienced silently, in a simplified, symbolic manner; not privately but collectively, together as a nation. Moreover, 'national' in the present Armenian sense of the word

20 For a description of a seventeenth-century pilgrimage from Zamosc, see Simeon of Poland (2007: 176-8). Of all those who came from Tbilisi, the most famous is undoubtedly the legendary bard Sayat Nova (d. 1795). 
means global: the presence of the diaspora on April 24th is intense and easily discernible. The attendance of Armenians from Argentina to Siberia makes the event simultaneously universal and national. ${ }^{21}$ The influx of the descendants of West Armenians especially contributes to a sense of timelessness in which the dividing lines of the state borders cease to exist for a moment. Moreover, the lack of symbolism makes the space equally open to atheist, Catholic and Protestant Armenians, in addition to the followers of the traditional Apostolic Church.

In recent years, another procession has evolved for the evening of April 23rd. After sunset, people march with torches from the city centre to the monument a few kilometres way. This procession is also a protest against a century of denial, and the silence that has supported denialism. The participants are mostly young people.

Likewise on April 24th, the huge proportion of youths amongst the participants is remarkable, at least when compared with any event of national character anywhere in Europe. One can say that there is no other event that as efficiently strengthens the Armenian identity and unifies Armenians across political, religious, linguistic and cultural barriers. It is remarkable that even Jews, despite the multitude of forms of remembrance, have no corresponding event in Jerusalem or anywhere.

What is perhaps even more interesting, however, is the implicit religious function of the post-genocide April 24th 'pilgrimages' to Tsitsernakaberd - in at least three senses. Firstly, the strengthening of Armenian national identity tends to contribute to a strengthening of religious identity, due to the national character of the Armenian Church. Secondly, the visit offers a unique, contemplative moment - a rare virtue in our times - with profound intimations of life and death. And finally, there is the substitutive function in relation to the lost cult of pilgrimage and ecclesiastical processions.

One might say that the national procession on April 24th is 'symbolic' in the sense of the word as it is used in the theology of the Eastern churches: being a symbol does not imply being an arbitrary mark, but a representation, manifestation and even embodiment

21 The West Armenians were present in the project from the very beginning, for the construction works included a lot of repatriates such as Armenian stonemasons from Kesab, Syria. of the symbolised (o $\mathrm{o}_{\mathrm{o}}(\omega \mu \alpha)$. The procession symbolises the vastness of absence by making it present in a crystallised manner.

\section{After the canonisation}

Along these lines, Tsitsernakaberd in general, and April 24th in particular, have multi-layered, albeit implicit, religious functions, even though substitutive in character. In addition, there is also the customary cultic activity in Tsitsernakaberd on this date, when a memorial service is conducted by the Katholikos and clergy inside the sanctuary.

The character of the prayers in Tsitsernakaberd, however, changed substantially in April 2015 when the martyrs of the genocide were canonised in a bold move by the Armenian Church. ${ }^{22}$ The boldness of this act resides in the fact that there had been no canonisations of new saints for hundreds of years in the Armenian Apostolic Church, and the whole process had to be created from almost zero. The martyrdom of 1915 as such corresponds rather unproblematically to the principles of classical Early Christian martyrdoms, even though the scale was unprecedented, for the criterion of annihilation utilised by the Turks was religious, not ethnic (genetic) or linguistic.

What exactly the sainthood of victims means for the remembrance of the genocide in practice remains to be seen, but what it should mean, from the Christian perspective, is rather clear. In principle, the destiny of the martyred people is no longer a matter of desperation and sorrow; no longer in need of our prayers, the Christian martyrs are heavenly characters whose intercession is a matter of hope and joyfulness.

Nevertheless, this applies to the martyred individuals only. The pain over the lost lands, monasteries, buildings, manuscripts, songs, dances and the whole West Armenian way of life still remains, especially in the West Armenian diaspora, in addition to the absurd denial still vehemently promoted by Turkey.

The setting means that after April 24th, 2015, the focus of remembrance has shifted from human souls more clearly to the lands and wider cultural topics. It goes without saying that not every Armenian believes or thinks in accordance with the teaching of

22 I have discussed this more thoroughly in Seppälä 2015: 354-64. 
the Church, but nonetheless the shift is obviously for more practical reasons also. A whole century having elapsed, the memory of individuals is inevitably passing into oblivion and is no longer a cause of mourning.

The memory of West Armenian life and culture, however, lives through its painful absence and by its commemorative re-enactments in Armenia and the diaspora. The loss of everything connected with that life is being enacted in the memorial of Tsitsernakaberd in a unique way from year to year, reconstructing Armenian identity through the embodied presence of centennial absence.

Therefore, one may say that Kalashyan and Tarkhanyan managed, in spite of all the Soviet oddities occurring throughout the process, to create a space that is architecturally sound, philosophically valid, and in a practical sense functioning. Particularly on April 24th, it succeeds in uniting all Armenians in a unique way that does some justice to their painful history.

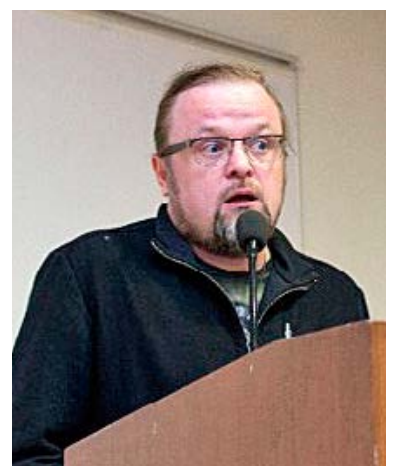

Serafim Seppälä, $\mathrm{PhD}$, is Professor of Systematic Theology in the University of Eastern Finland. In addition to his interest in the cultural legacy of the Armenian genocide, his publications include a variety of topics such as Syriac spirituality, encounters of Early Islam and Christianity, the idea of Jerusalem in three religions, Jewish and Christian angelology, Byzantine aesthetics and Byzantine Mariology.

\section{References}

Arevshatyan, Ruben, 2010. 'Blank zones in collective memory or the transformation of Yerevan's urban space in the 6os', Red Thread, issue 2, <http://www. red-thread.org/en/article.asp? $\mathrm{a}=33>$ (accessed 12.9.2016)

Arsenian Ekmekji, Arda, 2011. Towards Golgotha: The Memoirs of Hagop Arsenian, a Genocide Survivor (Beirut, Haigazian University Press)

Balyan, Karel, 2015. Memorial Egern (Yekateringburg, Tatlin)

Dadrian, Vahram, 2003. To the Desert: Pages from My Diary (Princeton and London, Gomidas Institute)

Hagopian Taft, Elise, 1981. Rebirth (New York, New Age Publishers)

Hovannisian, Richard (ed.), 2007. The Armenian Genocide: Cultural and Ethical Legacies (New Brunswick, Transaction Publishers)

Jinks, Rebecca, 2014. 'Situating Tsitsernakaberd: the Armenian Genocide Museum in a global context', International Journal of Armenian Genocide Studies, 1(1), pp. 39-52

Rosenfeld, Gavriel D., 2011. Building after Auschwitz: Jewish Architecture and the Memory of the Holocaust (New Haven, Yale University Press)

Rotem, Stephanie Shosh, 2013. Constructing Memory: Architectural Narratives of Holocaust Museums (Bern, Peter Lang)

Seppälä, Serafim, 2015. Vaienneita ääniä. Kunnianosoitus kadonneelle kulttuurille (Helsinki, Kirjapaja)

Simeon of Poland, 2007. The Travel Accounts of Simēon of Poland, tr. George A. Bournoutian, Armenian Studies Series (Costa Mesa, Mazda Publishers)

Stepanyan, Davit, 2015. Monuments Speaking Armenian (Yerevan)

Stone, Dan, 2013. The Holocaust, Fascism and Memory: Essays in the History of Ideas. (Basingstoke and New York, Palgrave and Macmillan)

Ter Minassian, Taline, 2007. Erevan. La construction d'une capitale á l'Époque Soviétique (Art \& Societe, Presses Universitaires de Rennes)

Tsitsernakaberd Memorial Complex, official web-page of the museum, <http://www.genocide-museum. am/eng/Description_and_history.php $>$ (accessed $14.5 .2016)$

Yervant, John, 1988. Needle, Thread and Button, Survivors' Memoirs, 2 (Zoryan Institute for Contemporary Armenian Research and Documentation) 